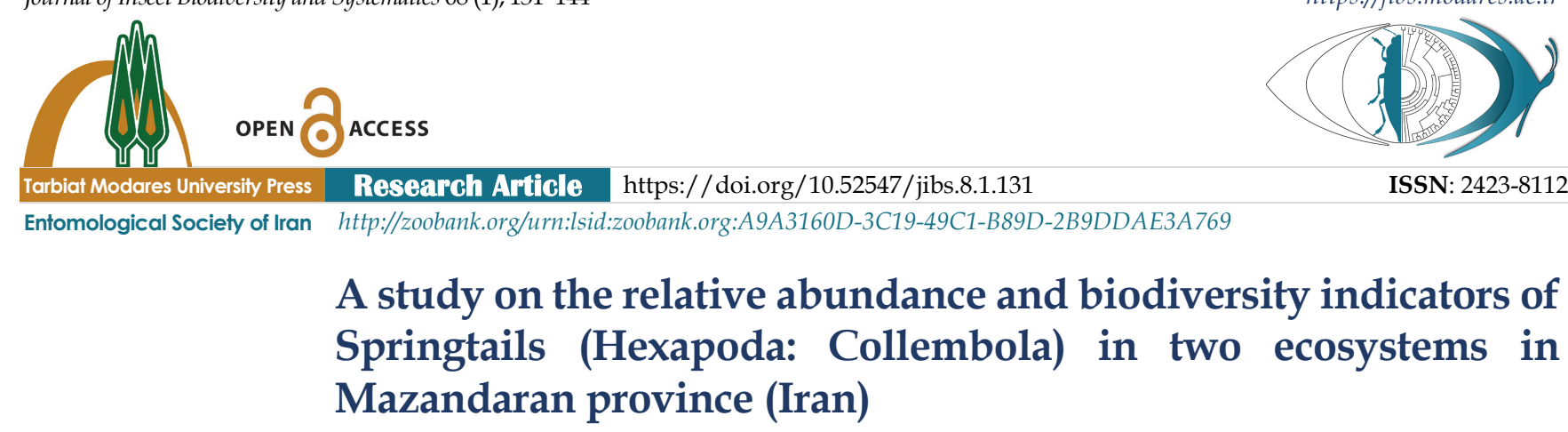

Eliye Yahyapour

Department of Entomology, Faculty of Agricultural Sciences, Islamic Azad University, Arak-Branch, Arak. هeyahyapur@yahoo.com; (i) https://orcid.org/0000-0002-4079-9430

\title{
Masoumeh Shayanmehr
}

Department of Plant Protection, Faculty of Crop Sciences, Sari university of Agricultural Sciences and Natural Resources(SANRU), Mazandaran province, Iran.

$\triangle$ Shayanm30@yahoo.com; (i) https://orcid.org/0000-0002-5024-1182

Behzad Miri

Department of Plant Protection, College of Agriculture, Razi University, Kermanshah, Iran. $\triangle$ behzadmiri664@gmail.com; (i) https://orcid.org/0000-0001-8869-6978

\section{Reza Vafaei Shoushtari}

Department of Entomology, Faculty of Agricultural Sciences, Islamic Azad University, Arak-Branch, Arak, Iran. $\triangle$ r-vafaei@iau-arak.ac.ir; (iD https://orcid.org/0000-0001-9436-1955

Received:

07 November, 2021

Accepted:

01 January, 2022

Published:

05 January, 2022

Subject Editor:

Francisco Javier Peris Felipo
ABSTRACT. In this study the biodiversity and relative abundance of Collembola was evaluated in two different ecosystems, citrus orchard and forest in Mazandaran province, Iran. Samples were carried out during 2016 and 2017. Species richness, biodiversity and the indices of similarity were calculated. The results of T-Test showed that in two years (2016 and 2017), the values of Shannon-Wiener diversity and Simpson species diversity index were significantly different between sampling areas (Pvalue $<0.05)$, but the values of Margalef richness and Pielou evenness index were not significantly (Pvalue $>0.05$ ). In the year 2016, Shannon-Wiener index, Simpson index, Pielou evenness and Margalef species richness in Dasht-e Naz forest were $1.92 \pm 0.1,0.83 \pm 0.03,2.01 \pm 0.2$ and $0.94 \pm 0.04$ respectively, and in citrus orchard were $1.44 \pm 0.11,0.73 \pm 0.02,1.46 \pm 0.37$ and $0.9 \pm 0.03$ respectively. Also, in the year 2017, Shannon-Wiener index, Simpson index, Pielou evenness and Margalef species richness in Dasht-e Naz forest were $1.79 \pm 0.05,0.81 \pm 0.08,1.38 \pm 0.25$ and $0.94 \pm 0.09$ respectively, and in citrus orchard were $0.98 \pm 0.22,0.58 \pm 0.08,1.02 \pm 0.35$ and $0.95 \pm 0.05$ respectively. In general, the results showed that the abundance and biodiversity of Collembola in Dasht-e Naz forest was higher than in citrus orchard.

Key words: Collembola, biodiversity, citrus, forest, Iran

Citation: Yahyapour, E., Shayanmehr, M., Miri, B. \& Vafaei Shoushtari, R. (2022) A study on the relative abundance and biodiversity indicators of Springtails (Hexapoda: Collembola) in two ecosystems in Mazandaran province (Iran). Journal of Insect Biodiversity and Systematics, 8 (1), 131-144.

\section{INTRODUCTION}

Collembola, commonly known as springtails, are small wingless soft-bodied hexapods that are usually between 1 and $3 \mathrm{~mm}$ in length. This group generally found occur in varying habits such as, soil surface and leaf litter, under rocks or the bark of trees. Also, they are free-living and omnivorous organisms, 
which prefer moist conditions (Paul et al., 2011). Springtails are one of the most important organisms in the soil and sandy sediments of river, wetlands and floodplain forests and plays an important role in the processes of vegetation decomposition and soil microstructure. They are hosts of many parasitic Protozoa, Nematoda, Trematoda and pathogenic bacteria and in turn are attacked by different predators. Such activities are critical to the functioning of ecosystems and the maintenance of soil health and high land productivity, both in natural ecosystems (such as forests) and in altered human ecosystems (e.g., agriculture) (Deharveng, 1995; Cincotta et al., 2000). Choi et al. (2008) showed that excessive use of pesticides, especially herbicides, are one of the factors that can influence the population fluctuations of springtails. They also stated that Paraquat herbicide can be used to reduce the incubation rate of springtails. Currently, there are many concerns about human activities to reduce biodiversity, and for this reason, in the recent decade, much attention has been paid to the importance of biodiversity conservation (Culik \& Filho, 2003). Relatively few studies have been conducted on the biodiversity of springtails. Cancela da Fonseca \& Sarkar (1998) investigated the effect of the agriculture on micro arthropods biodiversity. Their results showed that cropping has a positive effect on springtails abundance and biodiversity. Rusek (1998) showing that soil acidification, nitrogen supply, global climate change and intensive farming affect greatly impacted springtails diversity. Culik et al. (2002) studied biodiversity of springtails in tropical agricultural environments of Brazil. Where they observed that the total springtails densities were greater with no tillage versus conventional tillage and with mulch versus no mulch.

Moradi et al. (2019) studied species diversity of springtails (Hexapoda: Collembola) in four different ecosystems of Lorestan province, Iran. Their results showed that in both study areas, the diversity of forest species was more than in other ecosystems. In contrast, the field ecosystems of Khorramabad and Delfan rangeland had the least amount of species diversity. Mirab-balou \& Mahmoudi (2019) investigation of frequency and biodiversity of soil macrofauna under two different plant coverages (case study: Choqasabz forest park, Ilam province), Iran. They reported that the index of Shannon diversity, Pielou evenness and Margalef richness in Rosaceae plant coverages is higher than conifers. Kahrarian et al. (2017) studied the biodiversity of springtails in three different ecosystems in Kermanshah province, Iran. Their demonstrated the biodiversity and species richness of forest was higher than the field crop and grassland in two different cities. In Paveh, the species richness of the field crop was premier than the grassland. However, there was not significant difference between the field crop and grassland in Sare pol-e-Zahab, unexpectedly. Ramezani \& Mossadegh (2017) survey the effect of cropping on the diversity and density of springtails (Hexapoda: Collembola) in Khuzestan province, southwest of Iran. The species diversity by Shannon-Wienner index indicated that the diversity index was significantly higher $($ Pvalue $<0.05)$ in the field crops $(2.58 \pm 0.01)$ than in the abandoned field $(1.61 \pm 0.19)$ and the species densities in the field crops were more homogeneous.

The aim of this study was to evaluate the effect of ecosystem on the relative abundance and biodiversity of springtails communities in two different habitats (Dasht-e Naz forest and citrus orchard) Mazandaran province, north of Iran.

\section{MATERIAL AND METHODS}

The present investigation was performed in a Dasht-e Naz forest (Fig. 1B) and citrus orchard (Fig. 1C) which lies between $36^{\circ} 10^{\prime} 20^{\prime \prime} \mathrm{N}$ to $53^{\circ} 39^{\prime} 10^{\prime \prime} \mathrm{E}$. Located in the northeast of Sari, the center of Mazandaran province, Iran (Fig. 1A). The selected orchard is located near the Dasht-e Naz forest, the main crop of this land is citrus fruits. The citrus trees had between 15 and 20 years old. The soil of this site is a mixture of sand, silt, and clay, high enough to hold water and plant nutrients. The desired orchard used to be a forest, but its use has been changed for a long time and it has been turned into a citrus orchard. On the other human activities that cause the use of agricultural machinery, the extensive use of pesticides and chemical fertilizers as well as grazing sheep in orchards, which disrupts the physical and chemical properties of the soil. In 2016, the average of temperature and rainfall in spring was $20.03^{\circ} \mathrm{C}$ and $67.9 \mathrm{~mm}$, 
in summer $\left(27.5^{\circ} \mathrm{C}, 57.1 \mathrm{~mm}\right)$, autumn $\left(14.43^{\circ} \mathrm{C}, 95.05 \mathrm{~mm}\right)$ and winter $\left(8.73^{\circ} \mathrm{C}, 54.7 \mathrm{~mm}\right)$. Similar values were observed in 2017 where in spring the average of temperature was $19.26^{\circ} \mathrm{C}$ and rainfall $30.93 \mathrm{~mm}$, in summer was $28.16^{\circ} \mathrm{C}$ and $6.7 \mathrm{~mm}$, autumn $\left(15.93^{\circ} \mathrm{C}, 71.1 \mathrm{~mm}\right)$, and $9.93^{\circ} \mathrm{C}$ and $68 \mathrm{~mm}$ in winter.

\section{Sampling methods}

A seasonal sampling was carried out for each of the four seasons in two years 2016 and 2017. Ten soil samples were collected with a soil core of $5 \times 5 \mathrm{~cm}$ in surface area and a depth of $10 \mathrm{~cm}$ of from each of the two sampling sites i.e., forest and citrus orchard. The samples were tagged and sealed, transported to the laboratory and extracted by Tullgern funnels and examined individually (Fig. 2). The extracted specimens were sorted, and identified, by Fjellberg (1980, 1998, 2007), Bretfeld (1999) and Potapov (2001) keys.

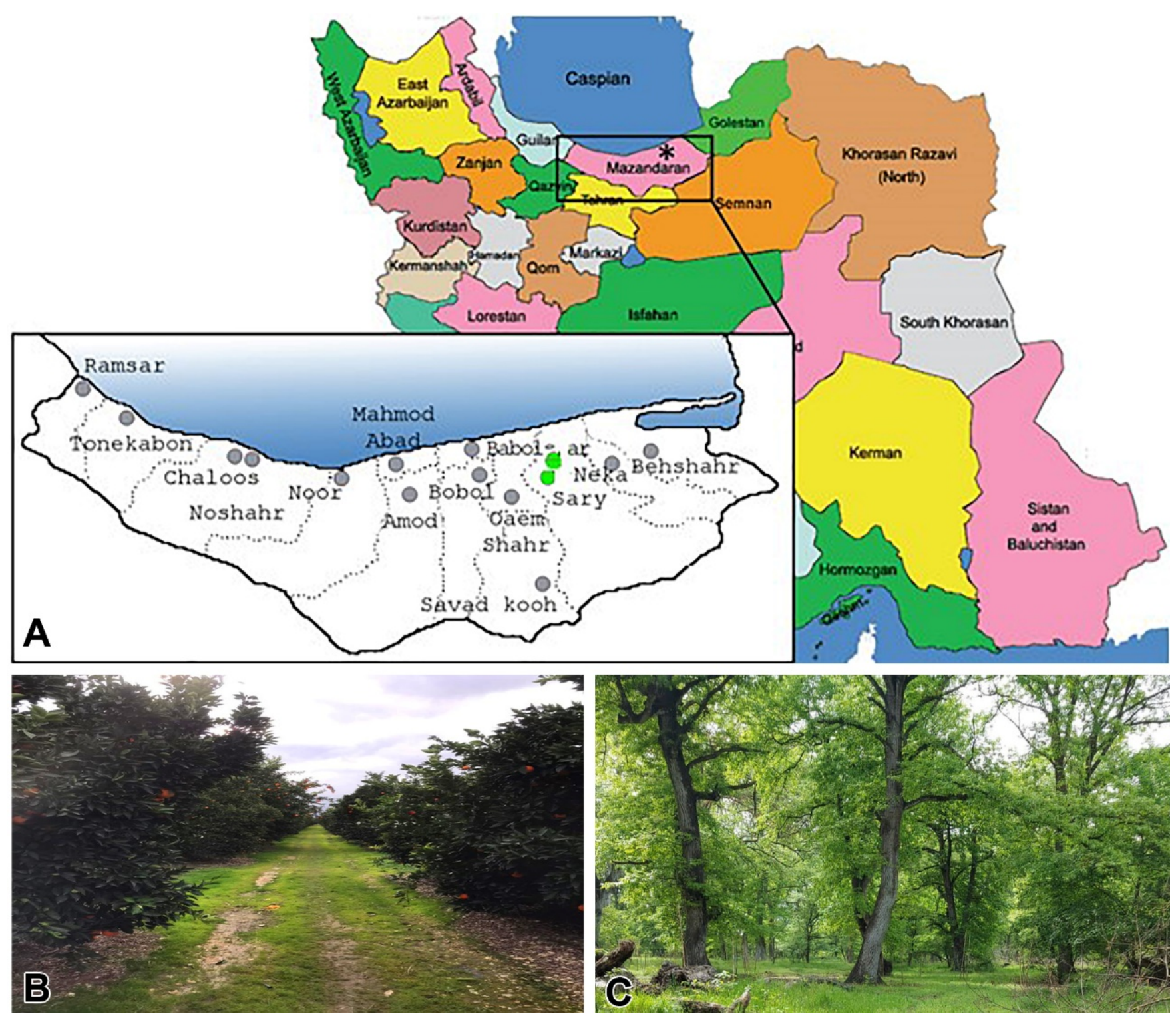

Figure 1. A. Map of the Mazandaran province of Iran, showing two location sites of study. B. Citrus orchard; C. Dasht-e Naz forest. 


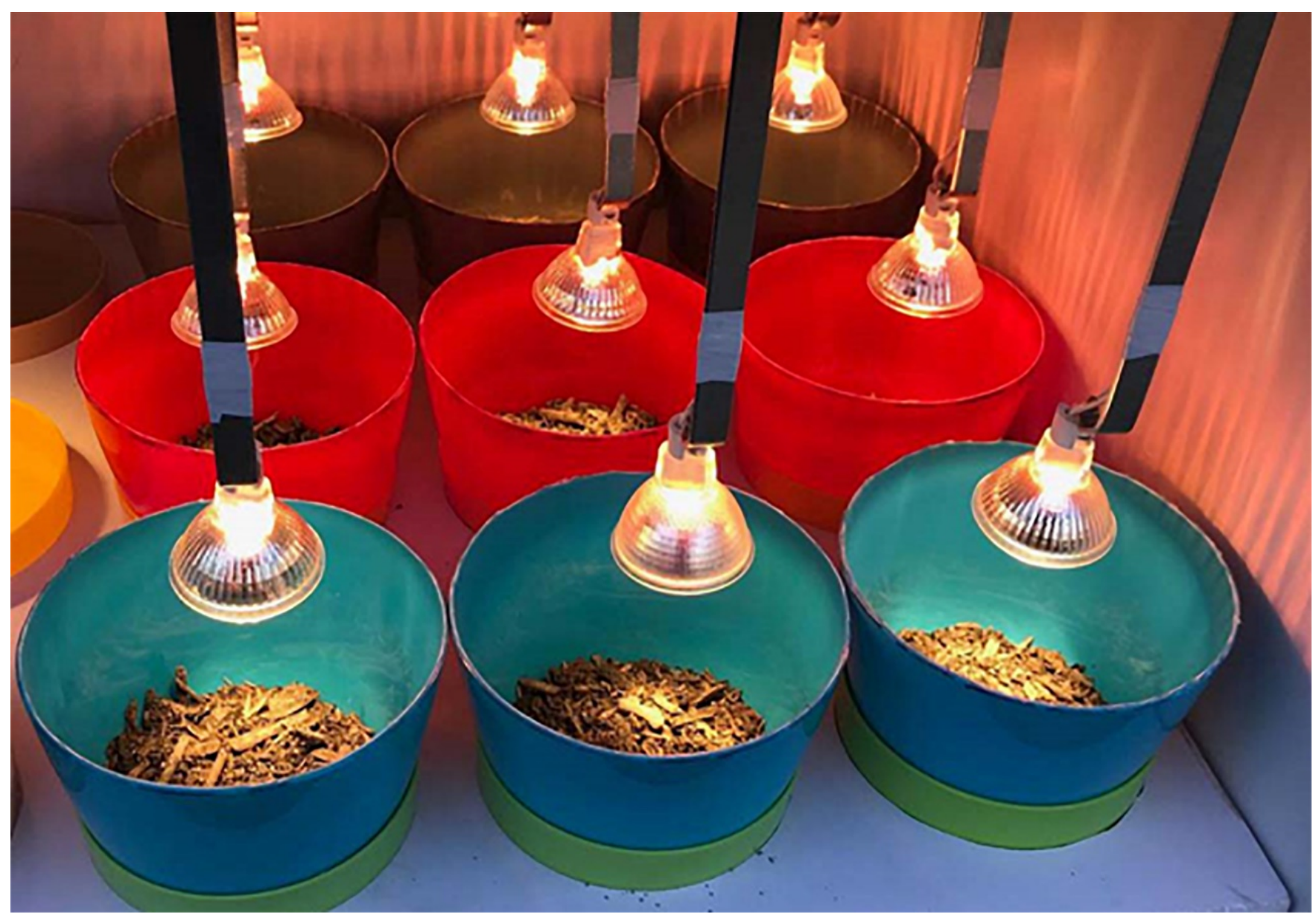

Figure 2. Extractor system for soil animals.

\section{Statistical Analysis}

Alpha ( $\alpha$ ), beta $(\beta)$ and gamma $(\Upsilon)$ diversity were calculated by Whittaker method (Whittaker, 1972). Alpha diversity expresses the diversity of species within a community or habitat. Beta diversity shows changes in the number of species from one ecosystem to another. The less common species there are in the two habitats, the greater the amount of beta diversity. Gamma diversity indicates the richness in species of a range of habitats in a geographical area. Domination coefficient informs what percentage out of the total amount of the collected specimens for a given area is constituted by specimens of a particular species. It was calculated by the following equation:

$$
D_{i}=\frac{n}{N} 100 \%
$$

In which, $D_{i}=$ dominance, $n=$ number of specimens of a given species in a given area and $N=$ number of all the specimens collected from a given area (Kasprzak \& Niedbala, 1981). Six classes of domination were as follows: Eudominant (30-100\%); Dominant (10-29.9\%); Subdominant (5-9.9\%); Rare (1-4.9\%); and Subrare $(<0.99 \%)$ (Weigmann 1973).

Shannon-Wiener's index: Was calculated by the following equation (Shannon \& Weaner, 1949):

$$
\mathrm{H}^{\prime}=-\sum_{i=1}^{s} \frac{n_{i}}{N} \ln \frac{n_{i}}{N}
$$

In which, $n_{i}=$ number of specimens of $i$-species per sample, $N=$ total number of individuals of all the species, and $s=$ number of species in community. 
Pielou index: Evenness was calculated by Pielou's evenness index which has two contributing components including the number of species and the distribution of individuals among those species:

$$
J=\frac{H^{\prime}}{\ln S}
$$

In which, $J=$ Pielou's evenness index, $H^{\prime}=$ Shannon-Wiener's index and $S=$ total number of species collected in the sample (Pielou, 1975). Simpson's index: Diversity was calculated by the following equation (Simpson, 1949):

$$
1-D=1-\sum_{i=1}^{S}(P i)^{2}
$$

In which $P_{i}=$ The proportion of individuals in the $i$ th species. Species richness was estimated using the Margalef's richness index (Margalef, 1958).

$$
\mathrm{D}_{m g}=\frac{S-1}{\operatorname{Ln} N}
$$

In which, $D_{m g}=$ Margalef's richness index, $S=$ the number of species recorded and $N=$ the total number of individuals in the sample. Also, similarity coefficients between two ecosystems were calculated by two indices of Sorensen (Ss) and Jaccard (Sj) (Magurran, 1988).

$$
S_{j}=\frac{j}{a+b-j} \quad S_{S}=\frac{2 j}{a+b}
$$

In which $j=$ the number of species found in both sites and $a=$ the number of species in site A with $b$ the number of species in site $B$.

As the data was fit a normal distribution according to the Kolmogorov-Smirnov test, therefore the one-way ANOVA to test was used the effect of seasons on diversity, richness and evenness of springtails. The means were compared using the Duncan test at a 5\% level of probability. The T-Test was used to determine the differences between the diversity indices in the sampling sites. The analyses were done using SPSS version 11. Also, springtails diversity (Shannon index) and (Simpson's index), evenness (Pielou index) and species richness (Margalef's) were calculated using the PAST, version 3.04 software (Hammer et al., 2001).

\section{RESULTS}

In this study, in total of 264 specimens (217 specimens in the Dasht-e Naz forest and 47 specimens in the citrus orchard) were collected. We identified a total of 20 species from 17 genera and eight different families of springtails (Table 1). Heteromurus major (Moniz, 1889) was the dominant species in Dasht-e Naz forest and citrus orchard with a frequency of $27.18 \%$ and $27.65 \%$, respectively (Table 1). Also, Entomobrya multifasciata Tullberg, 1871 with a frequency of $11.05 \%$ in Dasht-e Naz forest was ranked second, while H. gigans (Mari Mutt and Stomp, 1980) was the second more abundant in citrus orchard with a frequency of $14.90 \%$ (Table 1). The results of changes in the population of springtails in Dasht-e Naz forest showed that in both year 2016 and 2017, the population density of springtails was significantly different (Pvalue $<0.05)$ through the different seasons, but results in citrus orchard showed that only year 2016 was statistically significant (Pvalue $<0.05)$.

According to the results obtained in Dasht-e Naz forest in 2016, the highest and lowest densities of $5.80 \pm 1.92$ and $0.90 \pm 0.27$ number $/ \mathrm{m}^{2}$ were related to autumn and winter seasons, respectively, in 2017, the highest and lowest densities of $2.80 \pm 0.74$ and $0.20 \pm 0.21$ number $/ \mathrm{m}^{2}$ were related to the spring and summer seasons, respectively (Table 2). The results citrus orchard showed that in 2016, the highest and lowest densities of $0.70 \pm 0.21$ and $0.09 \pm 0.11$ number $/ \mathrm{m}^{2}$ were related to spring and winter seasons, respectively. Also, in 2017, the highest and lowest densities were respectively with the values of $0.60 \pm$ 0.30 and $0.10 \pm 0.11$ number $/ \mathrm{m}^{2}$ corresponded to the autumn and summer seasons (Table 2). 
Table 1. The number and frequency percentage of the different species of Collembola in Dasht-e Naz forest and citrus orchard of Mazandaran province, Iran.

\begin{tabular}{|c|c|c|c|c|c|c|c|}
\hline \multirow[b]{2}{*}{ Species } & \multirow[b]{2}{*}{ Family } & \multicolumn{3}{|c|}{ Forest } & \multicolumn{3}{|c|}{ Citrus orchard } \\
\hline & & 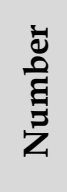 & 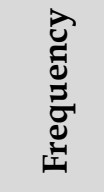 & $\begin{array}{l}\overrightarrow{0} \\
\stackrel{0}{0} \\
\stackrel{\Delta}{0} \\
0\end{array}$ & $\begin{array}{l}\text { పे } \\
\text { है } \\
\text { Zे }\end{array}$ & 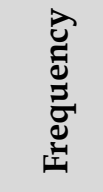 & $\begin{array}{l}\text { Dे } \\
\text { d्र } \\
\frac{0}{0} \\
\text { है }\end{array}$ \\
\hline $\begin{array}{l}\text { Ceratophysella stercoraria } \\
\text { Stach, } 1963\end{array}$ & Hypogastruridae & 10 & 4.60 & Rare & 1 & 2.12 & Rare \\
\hline $\begin{array}{l}\text { C. denticulata (Bagnall, } \\
\text { 1941) }\end{array}$ & $"$ & 3 & 1.38 & Rare & - & - & - \\
\hline $\begin{array}{l}\text { Xenylla welchi Folsom, } \\
1916\end{array}$ & $"$ & 20 & 9.21 & Subdominant & 1 & 2.12 & Rare \\
\hline $\begin{array}{l}\text { Entomobrya atrocincta } \\
\text { Schott, } 1986\end{array}$ & Entomobryidae & 2 & 0.92 & Subrare & - & - & - \\
\hline $\begin{array}{l}\text { E. multifasciata Tullberg, } \\
1871\end{array}$ & $"$ & 24 & 11.05 & Dominant & 6 & 12.76 & Dominant \\
\hline E. dollfusi Denis, 1924 & $"$ & 2 & 0.92 & Subrare & - & - & - \\
\hline $\begin{array}{l}\text { Heteromurus major } \\
\text { (Moniez, 1889) }\end{array}$ & $"$ & 59 & 27.18 & Dominant & 13 & 27.65 & Dominant \\
\hline $\begin{array}{l}\text { H. gigans (Mari Mutt \& } \\
\text { Stomp, 1980) }\end{array}$ & $"$ & 16 & 7.37 & Subdominant & 7 & 14.90 & Dominant \\
\hline $\begin{array}{l}\text { Seira domestica Nicolet, } \\
\quad 1842\end{array}$ & $"$ & 8 & 3.69 & Rare & - & - & - \\
\hline $\begin{array}{l}\text { Lepidocyrtus cyaneus } \\
\text { Tullberg, } 1871\end{array}$ & $"$ & 2 & 0.92 & Subrare & - & - & - \\
\hline $\begin{array}{l}\text { Pseudosinella octopunctata } \\
\text { Boner, } 1901\end{array}$ & $"$ & 2 & 0.92 & Subrare & 3 & 6.38 & Subdominant \\
\hline $\begin{array}{l}\text { Orchesella cincta } \\
\quad \text { (Linnaeus, 1758) }\end{array}$ & Orchesellidae & 13 & 5.99 & Subdominant & 3 & 6.38 & Subdominant \\
\hline $\begin{array}{l}\text { Isotomurus palustris } \\
\text { (Muller, 1776) }\end{array}$ & Isotomidae & 10 & 4.60 & Rare & 3 & 6.38 & Subdominant \\
\hline $\begin{array}{l}\text { Folsomides paroulus Stach, } \\
1922\end{array}$ & $"$ & 9 & 4.14 & Rare & 3 & 6.38 & Subdominant \\
\hline $\begin{array}{l}\text { Folsomia inoculate Stach, } \\
1947\end{array}$ & $"$ & 10 & 4.61 & Rare & 4 & 8.51 & Subdominant \\
\hline $\begin{array}{l}\text { Neanura persica Arbea, } \\
\text { Yahyapour \& } \\
\text { Shayanmehr, } 2021\end{array}$ & Neanuridae & 3 & 1.38 & Rare & - & - & - \\
\hline $\begin{array}{l}\text { Tomocerus vulgaris } \\
\text { (Tullberg, 1871) }\end{array}$ & Tomoceridae & 13 & 5.99 & Subdominant & 2 & 4.25 & Rare \\
\hline $\begin{array}{l}\text { Sminthurus ghilarovi } \\
\text { Stebaeva, } 1966\end{array}$ & Sminthuridae & 7 & 3.22 & Rare & 1 & 2.12 & Rare \\
\hline $\begin{array}{l}\text { Lipothrix lubbocki } \\
\text { (Tullberg, 1872) }\end{array}$ & $"$ & 2 & 0.92 & Subrare & - & - & - \\
\hline $\begin{array}{l}\text { Sminthurinus elegans } \\
\text { Fitch, } 1863\end{array}$ & Katiannidae & 2 & 0.92 & Subrare & - & - & - \\
\hline
\end{tabular}


Tabel 2. Average density of Collembola in the Dasht-e Naz forest and citrus orchard of Mazandaran province, Iran, years 2016 and 2017.

\begin{tabular}{|c|c|c|c|c|c|}
\hline Sampling location & Year & Season & Density (indm-2) & $F$ & Pvalue \\
\hline \multirow{4}{*}{ Dasht-e Naz forest } & \multirow{4}{*}{2016} & Spring (May) & $4.90 \pm 0.95 a$ & \multirow{4}{*}{3.59} & \multirow{4}{*}{$0.023^{*}$} \\
\hline & & Summer (August) & $3.50 \pm 0.61 a b$ & & \\
\hline & & Autumn (November) & $5.80 \pm 1.92 a$ & & \\
\hline & & Winter (February) & $0.90 \pm 0.27 b$ & & \\
\hline \multirow{4}{*}{ Citrus orchard } & \multirow{4}{*}{2016} & Spring (May) & $0.70 \pm 0.21 a$ & \multirow{4}{*}{3.10} & \multirow{4}{*}{$0.043^{*}$} \\
\hline & & Summer (August) & $0.10 \pm 0.10 b$ & & \\
\hline & & Autumn (November) & $0.60 \pm 0.26 a b$ & & \\
\hline & & Winter (February) & $0.09 \pm 0.11 b$ & & \\
\hline \multirow{4}{*}{ Dasht-e Naz forest } & \multirow{4}{*}{2017} & Spring (May) & $2.80 \pm 0.74 a$ & \multirow{4}{*}{5.71} & \multirow{4}{*}{$0.003^{* *}$} \\
\hline & & Summer (August) & $0.20 \pm 0.21 b$ & & \\
\hline & & Autumn (November) & $2.40 \pm 0.79 a$ & & \\
\hline & & Winter (February) & $0.30 \pm 0.29 b$ & & \\
\hline \multirow{4}{*}{ Citrus orchard } & \multirow{4}{*}{2017} & Spring (May) & $0.50 \pm 0.16 a$ & \multirow{4}{*}{1.27} & \multirow{4}{*}{$0.298^{\mathrm{ns}}$} \\
\hline & & Summer (August) & $0.10 \pm 0.11 a$ & & \\
\hline & & Autumn (November) & $0.60 \pm 0.30 a$ & & \\
\hline & & Winter (February) & $0.30 \pm 0.15 a$ & & \\
\hline
\end{tabular}

ns no significant difference

* significant difference at the level of 0.05

** significant difference at the level of 0.01

Comparison of species richness of springtails of Mazandaran province showed a greater alpha diversity in Dasht-e Naz forest than in citrus orchard. Similar results were observed with the general comparison of beta and gamma diversity 9 and 20, respectively (Table 3). The results of T-Test showed that in 2016 and 2017, the values of Shannon-Wiener diversity and Simpson species diversity index were significantly different between sampling areas (Pvalue<0.05), while Margalef richness and Pielou evenness index values were not significantly different (Fig. 3). The values of biodiversity indices of the population springtails on different seasons on Dasht-e Naz forest shown that in 2016, the highest value of Shannon-Wiener was 2.12 \pm 0.1 related to summer while the lowest value was $1.73 \pm 0.05$ related to season winter (Fig. 4). Similar results were observed by Pielou evenness index and Simpson index where the highest value (Pielou $=0.97$ \pm 0.10 ; Simpson $=0.87 \pm 0.12$ ) was obtained in summer and the lowest value (Pielou $=0.90 \pm 0.09$; Simpson $=0.80 \pm 0.14$ ) in autumn (Fig. 4). However, the values of Margalef index indicates that the highest values in winter $(2.27 \pm 0.12)$ and the lowest $(1.47 \pm 0.12)$ in autumn (Fig. 4$)$.
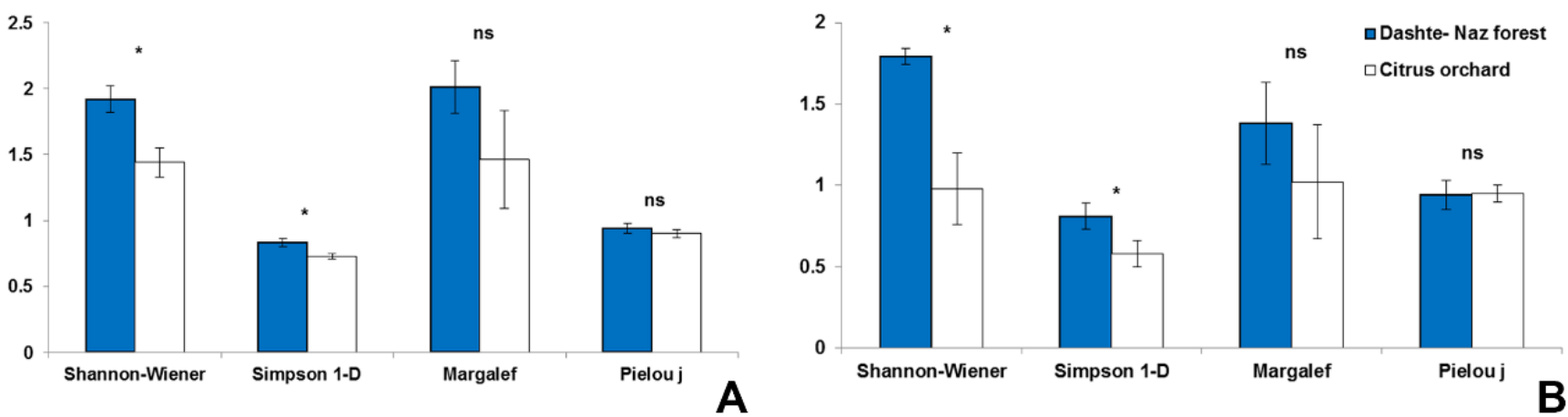

Figure 3. The numerical value of biodiversity indices between the Dasht-e Naz forest and citrus orchard, of Mazandaran province, Iran. A. 2016; B. 2017. (Non-similar alphabets represent a significant difference at the 5\% level). 
Table 3. Comparison of $\alpha, \beta$ and $\gamma$ biodiversity of Collembola in the Dasht-e Naz forest and citrus orchard of Mazandaran province, Iran.

\begin{tabular}{cccc}
\hline & \multicolumn{2}{c}{ Sampling location } \\
\hline Whittaker indices & Dasht-e Naz forest & Citrus orchard \\
\hline$\alpha$ & 20 & 12 \\
$\beta$ & & 9 & \\
$\Upsilon$ & & 20 & \\
\hline
\end{tabular}
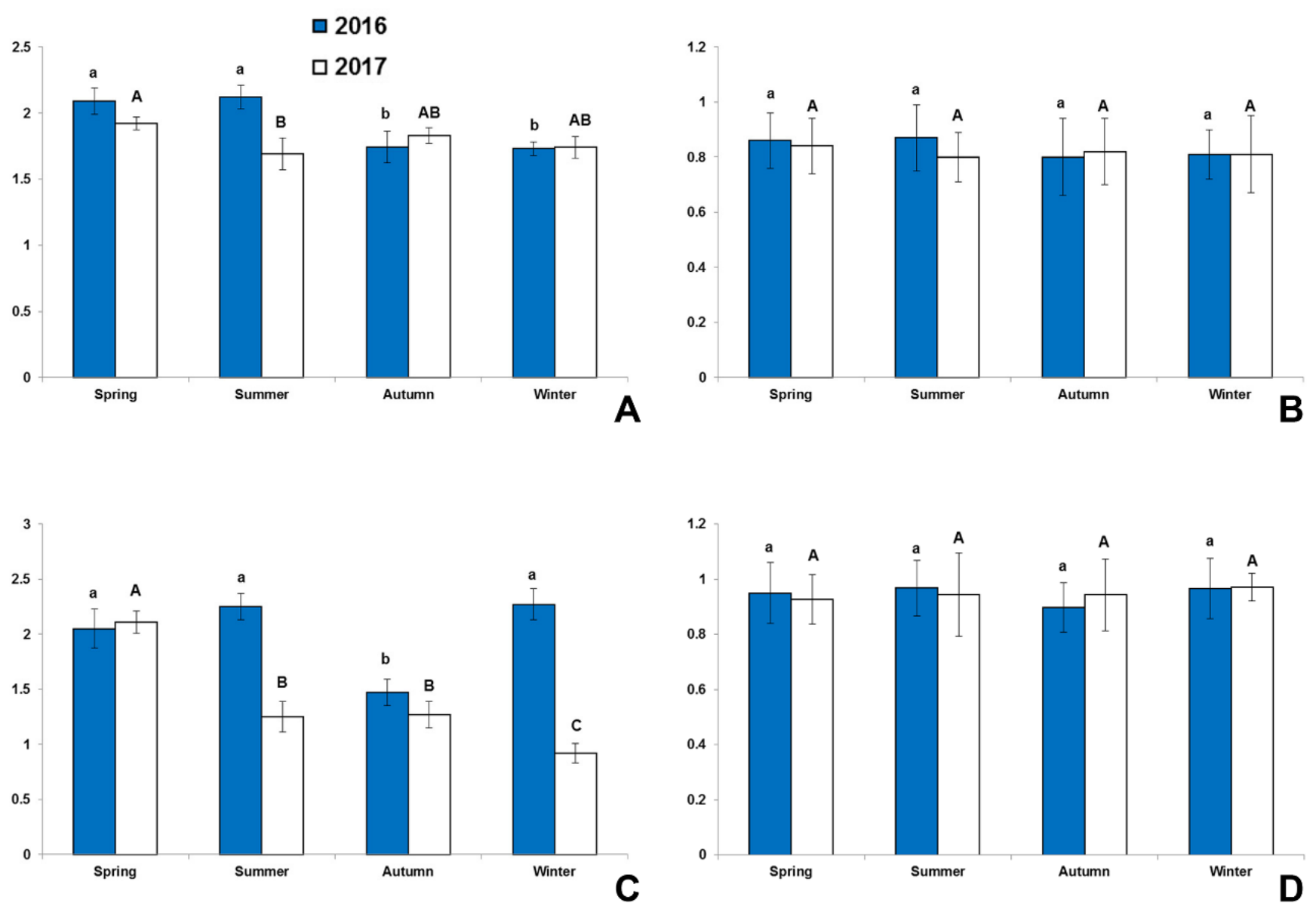

Figure 4. The numerical value of biodiversity indices in the Dasht-e Naz forest, of Mazandaran province, Iran, 2016 and 2017 years. A. Shannon-Wiener; B. Simpson 1-d; C. Margalef; D. Pielou J. (Non-similar capital and small letters represent a significant difference at the $5 \%$ level between sampling years).

Also, the values of biodiversity indices on Dasht-e Naz forest shown that in 2017, the highest value of Shannon-Wiener was $1.92 \pm 0.05$ related to spring while the lowest value was $1.74 \pm 0.08$ related to season winter (Fig. 4). Similar results were observed by Pielou evenness index and Simpson index where the highest value (Pielou $=0.97 \pm 0.05$; Simpson $=0.84 \pm 0.1$ ) was obtained in winter and spring, also the lowest value (Pielou $=0.92 \pm 0.09$; Simpson $=0.80 \pm 0.09$ ) in spring and summer (Fig. 4). However, the values of Margalef index indicates that the highest values in spring $(2.11 \pm 0.1)$ and the lowest $(0.92 \pm$ 0.09) in winter (Fig. 4). 
The values of biodiversity indices of the population springtails on different seasons on citrus orchard shown that in 2016, the highest value of Shannon-Wiener was $1.74 \pm 0.1$ related to spring while the lowest value was $1.27 \pm 0.34$ related to season autumn (Fig. 5). Similar results were observed by Pielou evenness index and Simpson index where the highest value (Pielou $=0.97 \pm 0.07$; Simpson $=0.81 \pm 0.04$ ) was obtained in spring and the lowest value (Pielou $=0.83 \pm 0.04$; Simpson $=0.69 \pm 0.07$ ) in winter and autumn (Fig. 5). However, the values of Margalef index indicates that the highest values in spring (2.57 $\pm 0.11)$ and the lowest $(0.90 \pm 0.18)$ in autumn (Fig. 5). Also, the values of biodiversity indices on citrus orchard shown that in 2017, the highest value of Shannon-Wiener was $1.60 \pm 0.1$ related to spring while the lowest value was $0.63 \pm 0.14$ related to season autumn (Fig. 5). Similar results were observed by Pielou evenness index and Simpson index where the highest value (Pielou $=0.99 \pm 0.09$; Simpson $=0.8$ \pm 0.09 ) was obtained in spring and the lowest value (Pielou $=0.91 \pm 0.1$; Simpson $=0.44 \pm 0.1$ ) in autumn (Fig. 5). However, the values of Margalef index indicates that the highest values in spring (2.5 \pm 0.14$)$ and the lowest $(0.28 \pm 0.12)$ in winter (Fig. 5). The results of similarity of species richness were calculated using Sorensen and Jaccard index. According to the results, the similarity values of species richness between Dasht-e Naz forest and citrus orchard based on Sorensen and Jaccard indices in 2016 were equal to 0.58 and 0.41 and in 2017 equal to 0.39 and 0.24 , respectively (Fig. 6).
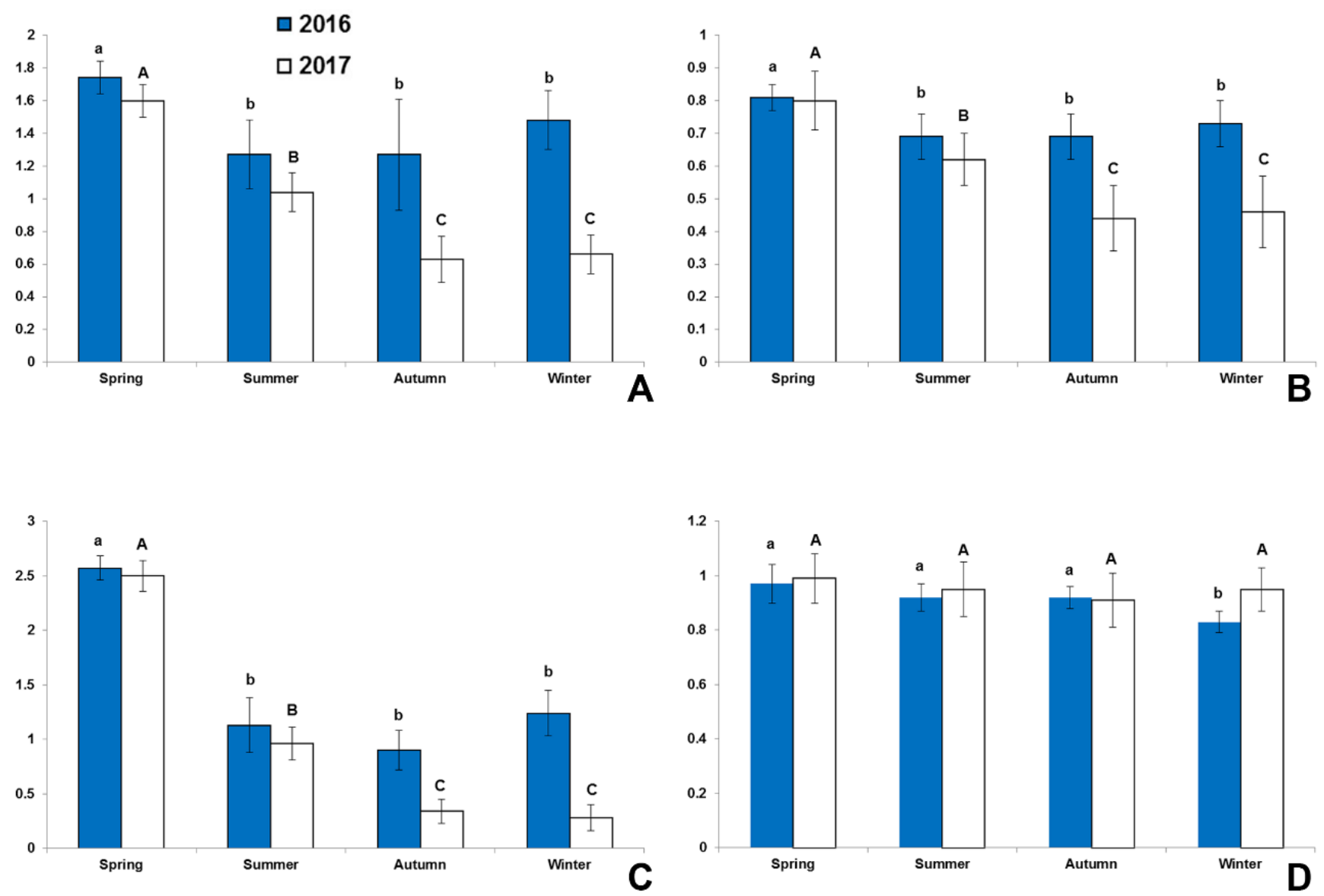

Figure 5. The numerical value of biodiversity indices in the citrus orchard, of Mazandaran province, Iran, 2016 and 2017 years. A. Shannon-Wiener; B. Simpson 1-d; C. Margalef; D. Pielou J. (Non-similar capital and small letters represent a significant difference at the $5 \%$ level between sampling years). 

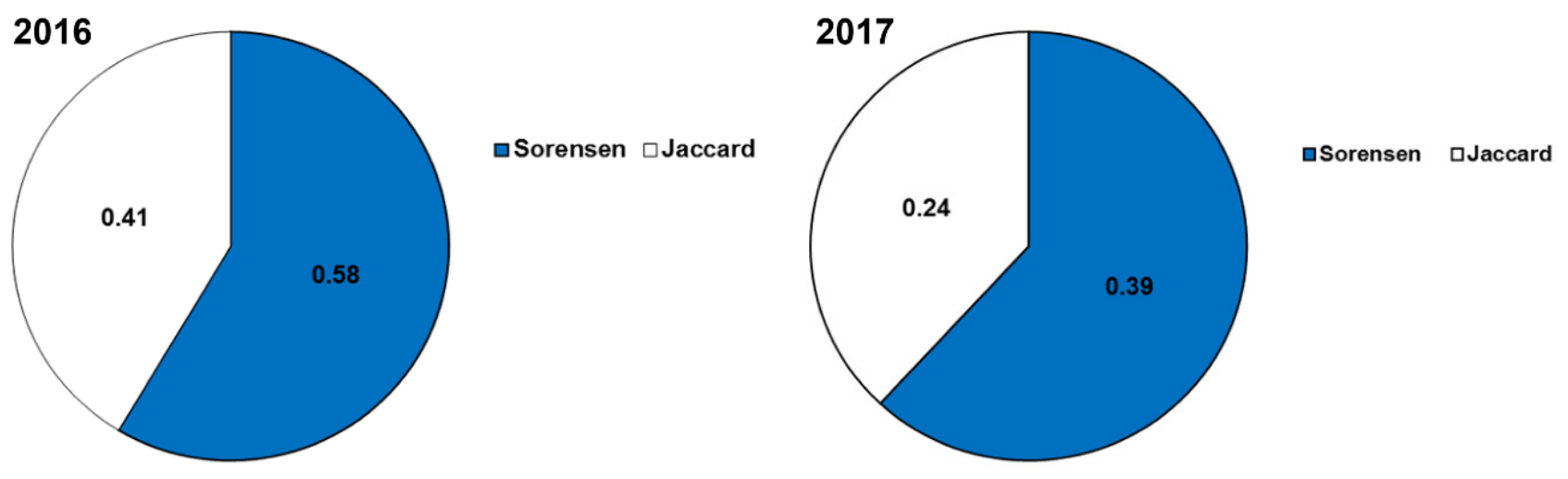

Figure 6. Comparison the similarity of Collembola in the Dasht-e Naz forest and citrus orchard, of Mazandaran province, Iran, 2016 and 2017 years.

\section{DISCUSSION}

Species diversity and relative abundance of springtails varies greatly with changes in physical and climatic conditions of an area. In this study the overall diversity and density of springtails was higher in the forest as compared to the citrus orchard. Maraun et al (2003) reported that forest ecosystems have a great species diversity than other ecosystems such as rangelands and crops. This may be indicative of the vast intensity of disturbance in the orchards as compared to the forest by way of tillage and irrigation which alter the soil structure. Other reasons include various factors such as proper leaf soil cover in forested areas, prevention of soil erosion due to rainfall and also soil enrichment due to the addition of organic elements and substances in the leaf soil (Moradi et al., 2019). Higher species diversity and density were recorded in spring, summer and autumn, when soil temperatures were higher than in winter. Also, the lowest density and diversity of springtails were recorded despite the high humidity in winter. On the other hand, an intense decrease in temperature in this season can be one of the reasons for the decrease in springtails population, as stated by Ilyas \& Parwez (2011), when the winter is very cold, the springtails population decreases. Among the collected species, H. major (Moniz, 1889) was introduced as the dominant species in Dasht-e Naz forest and citrus orchard with a frequency of $27.18 \%$ and $27.65 \%$, respectively. It seems that the species $H$. major, E. multifasciata and $H$. gigans are less sensitive to soil compaction and other factors in the soil as well as factors such as fertilizers and chemical pesticides than other species and therefore their frequency were higher compared to other species and were considered as the dominant species in both ecosystems.

In this study, the values of Shannon-Wiener index varied between a minimum of 0.98 in citrus orchard and a maximum of 1.92 in Dasht-e Naz forest. The variations of the Shannon-Wiener index ranged from zero to five and it is usually between 1.5 and 3.5. Values less than this range indicate the presence of stress in the environment and instability and higher values indicate an increase in biodiversity in the region (Ajmalkhan, 2004). Also, the values of Simpson species diversity index fluctuated from 0.83 in Dasht-e Naz forest to 0.58 in citrus orchard. This index emphasizes the dominant species in the sample because in Dasht-e Naz forest the number of H. major individuals was higher than citrus orchard. Sousa et al. (2006) reported that the Simpson diversity index of springtails in forest (0.31) is significantly higher than rangeland (0.12) and agriculture (0.28), which is consistent with the present study.

The amount of Margalef richness in this study varied between 2.01 in Dasht-e Naz forest and 1.02 in citrus orchard. Margalef species richness index indicates the number of species in a community and expresses the simplest biological concept. It indicates the suitability of the habitat for different species. The numerical value of this index decreases in adverse biological conditions or environmental stresses and increases with increasing number of species and density of each species because the use of herbicides in citrus orchard, as well as higher human intervention causing a constant disturbance, and affecting the 
richness in citrus orchard (Gamito, 2010). The value of Pielou evenness index ranged from 0.94 in Dashte Naz forest to 0.95 in citrus orchard. The evenness index can be a number between zero and one, and the maximum evenness index is obtained when the distribution of species has the most evenness. Huang et al. (2013) assessed the biodiversity of springtails in the three Gorge regions of China and showed that springtails biodiversity is systematically lost after urbanization and increased human intervention in the environment, which is consistent with the results of the present study. Kahrarian et al. (2017) showed that the relative abundance and diversity species of springtails in forest ecosystems was higher than agricultural and rangeland ecosystems, which is consistent with the results of the present study. Ramezani \& Mossadegh (2017) observed that Shannon-Wiener index in agricultural fields was significantly higher than abandoned fields, which is not consistent with the results of this study possibly because two regions are completely different. So that their study has been done in southern Iran with hot and dry climate and low rainfall, while the present study was carried out in the northern part of Iran with humid weather and high rainfall. Moradi et al. (2019) showed similar results in species diversity of springtails, where it was higher in forest ecosystems than agricultural, rangeland and fruit orchard ecosystems. In contrast, the field ecosystems of Khorramabad and Delfan rangeland had the least amount of species diversity. In general, Delfan city (with a Shannon value of 1.881) had a greater diversity of species than Khorramabad (with a Shannon value of 1.669), which is consistent with the results of the present study.

In general, the results showed that the abundance and biodiversity of springtails in Dasht-e Naz forest is higher than in citrus orchard. The highest abundance and diversity of species was obtained in May, August and November, which indicates that soil temperature conditions can have a great impact on the population of springtails. Furthermore, the high rate of human activity in orchards can be one of the important factors that reduce the biodiversity of springtails. Therefore, to prevent the biodiversity loss, human activity in orchards should be reduced or propery managed. Changing the use of forest to orchard disturbs the balance of the soil and due to the high use of herbicides as well as the use of agricultural machinery that compacts the soil in the orchard, reduces the population and the diversity of springtails and other soil organisms. In such cases, minimal use of tillage operations as well as less use of agricultural machinery, pesticides and herbicides will cause less change in the chemical and physical properties of the soil and help maintain the density and diversity of soil organisms.

\section{AUTHOR'S CONTRIBUTION}

The authors confirm contribution in the paper as follows: B.M and R.V.SH. both analyzed the data. E.Y.: sampling and preparetion onto slides. M.SH.M.: identification of specimens. All authors wrote the manuscript, discussed the results and contributed to the final manuscript.

\section{FUNDING}

This workd was funded by the Research Vice-Chancellor of the Islamic Azad University, Arak Branch and Department of Natural Resources and Forestly of Mazandaran Province.

AVAILABILITY OF DATA AND MATERIAL

Not applicable.

ETHICS APPROVAL AND CONSENT TO PARTICIPATE

Not applicable.

\section{CONSENT FOR PUBLICATION}

Not applicable. 


\section{CONFLICT OF INTERESTS}

The authors declare that there is no conflict of interest regarding the publication of this paper.

\section{ACKNOWLEDGMENTS}

Our sincere thanks to Nerivania Nunes Godeiro (Brazil) (Departamento de Botanica e Zologia, Centro de Biociencias, University Federal d Rio Grande Norte, Natal, RN, Brazil) for great helps in identifications of specimens. Special thanks to the editor and reviewers for their valuable comments and recommendations on the earlier version of the manuscript.

\section{REFERENCES}

Ajmalkhan, S. (2004) Methodology for Assessing Biodiversity, Annamalai University. Centre of Advanced Study in Marine Biology, 12 pp.

Bretfeld, G. (1999) Symphypleona. In: Dunger, W. (ed.) Synopses on Palaearctic Collembola, Vol. 2. Staatliches Museum für Naturkunde Görlitz, pp. 1-318.

Cancela da Fonseca, J.P. \& Sarkar, S. (1998) Soil microarthropods in two different managed ecological systems (Tripura, India). Applied Soil Ecology, 9, 105-107. https:/ / doi.org/10.1016/S0929-1393(98)00062-6

Choi, W.I., Neher, D.A. \& Ryoo, M.I. (2008) Life-history trade-offs of Paronychiurus kimi (Lee) (Collembola: Onychiuridae) populations exposed to paraquat. Ecotoxicology and Environmental Safety, 69, 227-232. https://doi.org/10.1016/j.ecoenv.2007.01.008

Cincotta, R.P., Wisnewski, J. \& Engelman, R. (2000) Human population in the biodiversity hotspots. Nature, 404, 990992. https://doi.org/10.1038/35010105

Culik, M.P. \& Filho, D.Z. (2003) Diversity and distribution of Collembola (Arthropoda: Hexapoda) of Brazil. Biodiversiy and Conservation, 12 (6), 1119-1143. https:/ / doi.org/10.1023/A:1023069912619

Culik, M.P., Jacimar, L.D.S. \& Jose, A.V. (2002) Biodiversity of Collembola in tropical agricultural environments of Esp'́rito Santo, Brazil. Applied Soil Ecology, 21, 49-58. https:/ / doi.org/10.1016/S0929-1393(02)00048-3

Deharveng, L. (1995) High diversity and community permeability: the riparian collembolan (Insecta) of a pyrenean massif. Hydroobiologia, 312, 59-74. https:/ / doi.org/10.1007/BF00018887

Fjellberg, A. (1980) Identification Keys to Norwegian Collembolan. Norsk Entomologisk Forening, 1-152.

Fjellberg, A. (1998) The Collembola of Fennoscandia and Denmark. Part I. Poduromorpha. Brill, Leiden, Boston. 183 pp.

Fjellberg, A. (2007) The Collembola of Fennoscandia and Denmark. Part II. Entomobryamorpha and Symphypleona. Brill, Leiden, Boston. 265 pp. https://doi.org/10.1163/ej.9789004157705.i-265

Gamito, S. (2010) Caution is needed when applying Margalef diversity index. Ecological Indicators, 10, 550-551. https://doi.org/10.1016/j.ecolind.2009.07.006

Hammer, O., Harper, D.A.T. \& Ryan, P.D. (2001) PAST- Palaeontological Statistics Software Package for Education and Data Analysis. Palaeontologia Electronica, 4 (1), 1-9.

Huang, C., Wang, T., Luo, Y., Chen, S. \& Kim, K.C. (2013) Assessing Collembola biodiversity under human influence at three Gorges area China. Environmental of Entomology, 2 (2), 214-222. https:// doi.org/10.1603/EN12253

Ilyas, M. \& Parwez, H. (2011) Effect of Agricultural practices on the population of Collembola. The Bioscan, 6 (2),191194.

Kahrarian, M., Vafaei-Shoushtari, R. \& Soleyman-Nejadian, E. (2017) Investigating biodiversity of springtails (Hexapoda: Collembola) in three different ecosystems in Kermanshah province, Iran. Plant Protection (Scientific Journal of Agriculture), 40 (3), 39-52.

Kasprzak, K. \& Niedbała, W. (1981) Biocenotic indicators in quantitative research. In: Górny M. \& Grüm, L. (eds) Methods Applied in Soil Zoology, PWN, Warszawa, pp:397-416.

Magurran, A. E. (1988) Ecological Diversity and its Measurement. Princeton University Press, New Jersey. 179 pp. https://doi.org/10.1007/978-94-015-7358-0 
Maraun, M., Salamon, J., Schneider, K., Schaefer, M. \& Scheu, S. (2003) Oribatid mite and collembolan diversity, density and community structure in a modern beech forest (Fagus sylvatica): effects of mechanical perturbations. Soil Biology and Biochemestery, 35, 1387-1394. https://doi.org/10.1016/S0038-0717(03)00218-9

Margalef, M. (1958) Information theory in ecology. Journal of General Systematics, 3, 36-71.

Mirab-balou, M. \& Mahmoudi, M. (2019) Investigation of frequency and biodiversity of soil Macrofauna under two different plant coverages (Case Study: Choqasabz Forest park, Ilam province). Journal of Soil Biology, 6 (2), 157166.

Moradi, T., Vafaie, R., Kahrarian, M. \& Mohseni Amin, A. (2019) Species diversity of Springtails (Hexapoda: Collembola) in four different ecosystems of Lorestan province, Iran. Taxonomy and Biosystematics, 11 (4), 101-116.

Paul, D., Nongmaithem, A. \& Jha, L.K. (2011) Collembolan density and diversity in a forest and agroecosystem. Soil Science, 1 (1), 54-60. https:/ / doi.org/10.4236/ojss.2011.12008

Pielou, E.C. (1975) Ecological Diversity. John Wiley \& Sons, New York. viii + 165 pp.

Potapov, M. (2001) Isotomidae. In: Dunger, W. (ed.) Synopses on Palaearctic Collembola. Vol.3. Staatliches Museum für Naturkunde Görlitz, pp. 1-603.

Ramezani, L. \& Mossadegh, M.S. (2017) The effect of cropping on diversity and density of springtails (Hexapoda: Collembola) in Khuzestan province, southwest of Iran. Journal of Entomological Research, 8 (4), 51-57.

Rusek, J. (1998) Biodiversity of Collembola and their functional role in the ecosystem, Biodiversity and Conservation, 12, 1207-1219. https:// doi.org/10.1023/A:1008887817883

Shannon, C.E. \& Weaner, A. (1949) The Mathematical Theory of Communication. University of Illinois Press, Urbana. 350 pp.

Simpson, E. H. (1949) Measurement of diversity. Nature, 12, 1-20. https:/ / doi.org/10.1038/163688a0

Sousa, J.P., Bolger, T., da Gama, M.M., Lukkari, T., Ponge, J.F., Simón, C., Traser, G., Vanbergen, A.J., Brennan, A., Dubs, F., Ivitis, E., Keating, A., Stofer, S. \& Watt, A.D. (2006) Changes in Collembola richness and diversity along a gradient of land-use intensity: a pan European study. Pedobiologia, 50, 147-156. https://doi.org/10.1016/j.pedobi.2005.10.005

Weigmann, G. (1973) Zur Okologie der Collembolen und Oribatiden im Grenzbereich Land-Meer (Collembola, Insecta Oribatei, Acari). Zeitschrift fur wissenschartliche Zoologie, 3-4, 295-391.

Whittaker, R.H. (1972) Evolution and measurement of species diversity. Taxon, 21 (2-3), 213-251. https:/ / doi.org/10.2307/1218190 
بررسى فراوانى نسبى و شاخصهاى تنوعزيستى یادمان (Hexapoda: Collembola) در دو اكوسيستم در استان مازندران (ايران)

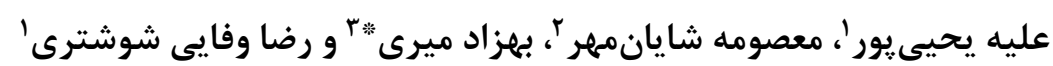
ا گَروه حشرهشناسى، دانشكده علوم كشاورزى، دانشكاه آزاد اسلامى، واحد اراك، اراك، ايران.

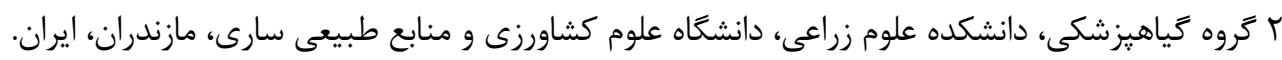

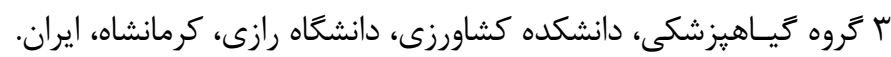

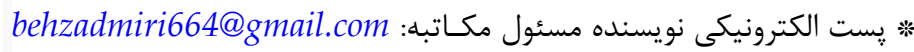

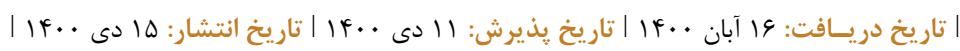

جكيـده: در اين مطالعه تنوعزيستى و فراوانى نسبى ڤِادمان در دو اكوسيستم مختلف،

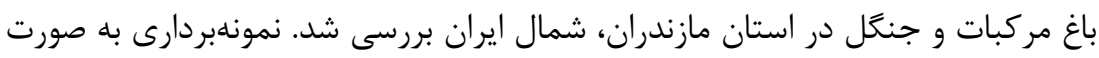

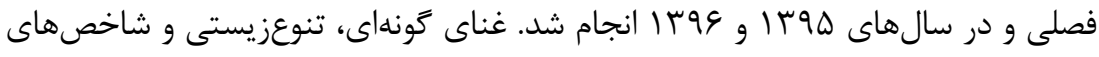

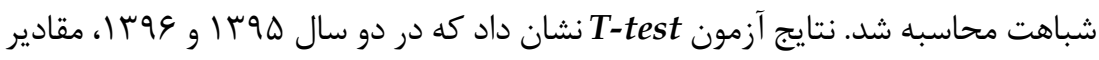

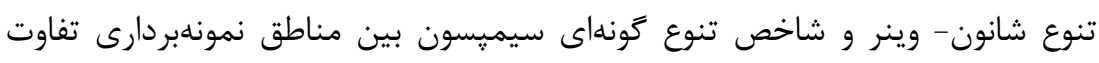

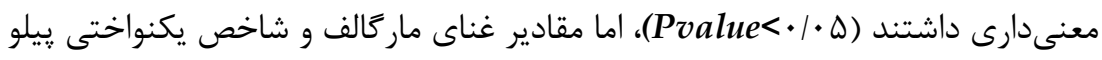

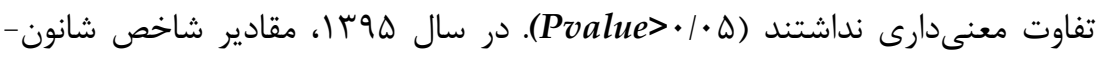

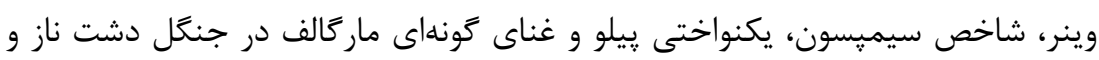

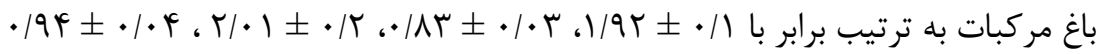

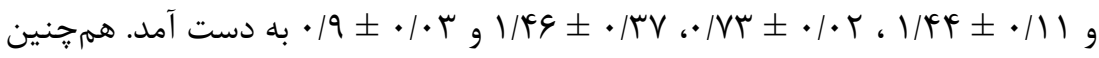

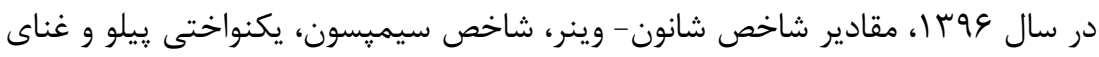

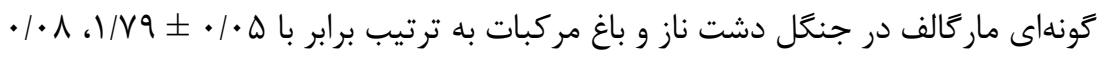

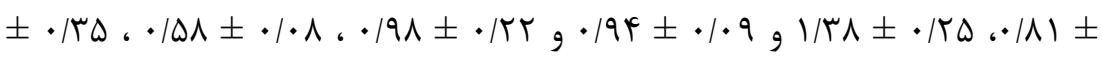

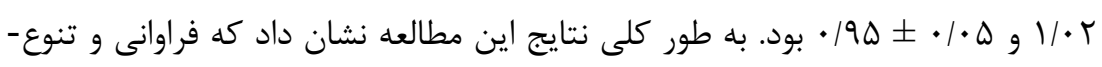

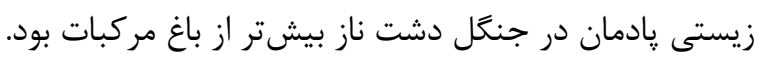
وارَّــان كليدى: يادمان، تنوعزيستى، مركبات، جنَّل، ايران 